\title{
Human Rights and Labour Standards from the Public Health Perspective in the World Trade Organization: Challenges and Possible Solutions
}

\author{
Karina Palkova and Giga Abuseridze \\ Researcher, Faculty of Law at Riga Stradins University, Riga, Latvia
}

Correspondence should be addressed to: Karina Palkova; karina.palkova@rsu.lv

Received date: 19 March 2020; Accepted date: 22 May 2020; Published date: 24 July 2020

Academic Editor: Ryszard Kozłowski

Copyright (C 2020. Karina Palkova and Giga Abuseridze . Distributed under Creative Commons Attribution 4.0 International CC-BY 4.0

\begin{abstract}
This study investigates the effects of the interaction between labor standards and human rights that has become a key issue in the World Trade organization. Policy makers gradually developed new rules to achieve both trade and human rights objectives. England signed treaties with the U.S., Portugal, Denmark and Sweden to ban trade in slaves ect. The trade labour linkage has a long history. It has become one of the most contentious contemporary issues in trade and labour policy circles and debates. The idea of using international labour standards to protect workers from economic exploitation was first promoted by individual social reformers in Europe in the first half of the nineteenth century during the early stages of the industrial revolution. Calls for an international labour legislation increased dramatically during the second half of the nineteenth century and found expression in various international organizations that were formed (often international associations of trade unions). Besides, international trade policy and labor standards can also hurt the right to health, directly or indirectly. As a result, there are several problems which can be identified regarding the International rules on trade as a whole and from the public health perspective. Without the national or international required action, international trade will not bring prosperity to all, but, on the contrary, it is likely to result in more income inequality, social injustice, environmental degradation and cultural homogenization.
\end{abstract}

Keywords: Human Rights, World Trade Organization, Public Health.

\section{Introduction}

According to S. Charnovitz (Charnovitz, 1987), the trade labour linkage has a long history. It has become one of the most contentious contemporary issues in trade and labour policy circles and debates (Langille, 1997). The idea of using international labour standards to protect workers from economic exploitation was first promoted by individual social reformers in Europe in the first half of the

Cite this Article as: Karina Palkova and Giga Abuseridze (2020), "Human Rights and Labour Standards from the Public Health perspective in the World Trade Organization: challenges and possible solutions", Journal of Economics Studies and Research, Vol. 2020 (2020), Article ID 423674,

DOI: $10.5171 / 2020.423674$ 
nineteenth century during the early stages of the industrial revolution. The work of these reformers was later taken over by various non-governmental organizations. Calls for an international labour legislation increased dramatically during the second half of the nineteenth century and found expression in various international organizations that were formed (often international associations of trade unions).

Opponents of labor standards argue that the international pressure on the foreign countries is an unnecessary and counterproductive interference in the workings of the free market. In this view, the pressure for international labor standards represents either a disguised protectionism or a misplaced compassion. Proponents of labor standards argue that a set of minimal labor standards is necessary to promote fair competition and to facilitate efficient operation of the labor market. In industrialized countries, there has also been a growing undercurrent of resentment toward trade with countries with low labor costs, which threatens the viability of international trade agreements. The core areas of labor standards typically include freedom of association, collective bargaining, prohibition of forced labor, elimination of exploitative child labor and nondiscrimination.

The International Labor Organization (ILO) has been the main institution concerned with international labor standards since its inception in 1919. The ILO establishes conventions that are binding only on the countries that ratify them. The ILO is not empowered to enforce compliance with ratified conventions; instead, it relies on the international pressure, advice and monitoring to encourage compliance. Additionally, several bilateral and multilateral trade agreements cover labor and environmental standards. For example, the labor side agreements were a critical element of the North American Free Trade Agreement (NAFTA). But how does it collaborate with public health?

\section{The International Labor Organization and its role from the Human rights perspective}

The (ILO) formally entered the trade labour interface debate in 1994 at the time of discussing a possible inclusion of a social clause in the WTO, the establishment of a link between trade and labour in different forms within NAFTA and the EU, and the conditioning of trade preferences and concessions by some developed countries in respect for labour standards. The ILO set up a working party on the social dimensions of the liberalization of international trade, but in 1995, the ILO's governing body concluded that the working party would not pursue the question of trade sanction and that further discussions of a link between international trade and social standards or a sanctionbased social clause mechanism would be suspended. With respect to trade and labor standards linkages in regional trading arrangements, within the EU, the social dimension of the European integration took a concrete form in 1991, when 11 of the 12 Member States (excluding the UK) signed the community's Charter of Fundamental Social Rights. Another important step in the development of EU social policy was the adoption by the 11 members (excluding the UK) of the protocol on Social Policy at Maastricht in 1991 (Trebilock, Howse and Eliason, 2013).

Recently, the debate over trade and labour rights has been extended to human rights more generally as an entirely logical development. However, in the case of other human rights, the debate is much less focused on 'linkage', including sanctions, and much more on the effects of trade obligations on the ability of states, especially developing countries, to fulfill economic, social and cultural rights, such as the right to health or to adequate food. Here, developing countries, although wary about sanctions, have been generally supportive of the efforts to evaluate and interpret trade agreements in human rights terms (Alben, 2001). 


\section{Core labour standards (CLS) and human rights}

Various CLS have been characterized by the UN Universal Declaration of Human Rights, the subsequent international Covenant on Civil and Political Rights, and International Covenant on Economics, social and Cultural rights. Important role plays the principle of socially responsible state, that means that state is obliged to establish sustainable and balanced policies to ensure public welfare. The country must ensure a balance between its financial capabilities and not just personal rights in the social area, but also a need to ensure the welfare of entiry society, creating legal regulations that are aimed at sustainable development of the country (Janis Grasis, 2016). The ILO's 1998 Declaration of Fundamental Principles and Rights at Work enumerates a short list of core international labour standards that are defined more fully in eight background Covenants incorporated by reference, namely, freedom of association and collective bargaining, the elimination of forced labour, the elimination of child labour and the elimination of discrimination in employment, which is also consistent with the characterization of certain core labour standards or rights as human rights, especially those that guarantee basic freedom of choice in employment relations (Michaeel, Trebilcock and Howse, 2005). Labour standards have been used in the Generalized System of Preferences as a preferential system to provide a duty free access to exports of developing countries by (most notably) the European Union and the United States of America. Currently, there is a revision of the EU's GSP scheme, in terms of the considerable potential implications, given that the new GSP plus scheme appears to target not only the ratification of the fundamental Conventions, but also the application of Conventions in line with comments from the ILO supervisory bodies. This has the potential to be very problematic for employers.Anartya Sen argues, in his book 'Development as Freedom', that the basic goals of development can be conceived of in universalistic terms, where the individual's well-being can plausibly be viewed as entailing certain basic freedoms irrespective of the cultural context:

1. Freedom to engage in political criticism and association;

2. Freedom to engage in market transactions;

3. Freedom from the ravages of preventable or curable diseases;

4. $\quad$ Freedom from the disabling effects of illiteracy and lack of basic education;

5. Freedom from extreme material privation. (Sen, 1999).

According to Sen, these freedoms have both intrinsic and instrumental values. Importantly, in contrast to the unfair competition and race to the bottom rationales for linking international trade policy and international labour standards, the human rights perspective focuses primarily on the welfare of the citizens in exporting, not importing countries. The assumption underlying this concern for basic or universal human rights is that failure to respect them in any country is either a reflection of the decision of unrepresentative or repressive governments rather than the will of the citizens or a sign of the majoritarian's oppression of the minorities, for example, children, women or racial religious minorities; alternatively, there may be paternalistic concerns that citizens in other countries have made uninformed or illadvised choices to forgo these basic rights.

The linkage of the international trade policy, including trade or other economic sanctions, with CLS that reflect basic or universal human rights is a cogent one. When citizens in some countries observe gross or systematic abuses of human rights in other countries, the possible range of reactions open to them include diplomatic protests, withdrawal of ambassadors, cancellation of air landing rights, trade sanctions or more comprehensive economic boycotts, or at the limit, military intervention.

Arguing that doing nothing is always or often the most appropriate response is inconsistent with the very notion of 
universal human rights. In extreme cases, such as war crimes, apartheid, the threat of chemical warfare in the case of Iraq, genocide in the case of Serbia, or the Holocaust in the case of Nazi Germany, excluding a priori economic sanctions form the menu of possible options, seems indefensible. Whether it is the most appropriate option may, of course, be context specific and depend both on the seriousness of the abuses and on the likely efficacy of the response choice of the instrument, issues to which we turn next. But it is sufficient for present purposes to restate the point that, to the extent that CLS are appropriately characterized as basic or universal human rights, a linkage between trade policy and such labour standards is not only defensible but arguably imperative, in contrast to the other two rationales for such a linkage which, despite their much longer historical lineage, are largely spurious and inconsistent with the central predicates of a liberal trading system. However, CLS viewed as basic or universal human rights, by promoting human freedom of choice, are entirely consistent with a liberal trading regime that seeks to ensure other human freedoms, in particular, the right of individuals to engage in market transactions with other individuals without discrimination on the basis of country or location (Molatlhegi, 2002). Having said this scope and the definition of the viewed human rights as sufficiently universal as to potentially warrant the imposition of trade sanctions for their violation is problematic in various respects. Even CLS are not susceptible to uncontentious understandings of their scope. The scope of many economic, social and cultural rights is controversial (Ignatiefee, 2001). These controversies do not obviate the normative force of the rights themselves, but do have implications for the choice of instruments and the choice of the institutional arrangement for addressing the trade policy-labour standards linkage, to which we now turn. As regards to a developing country: From a developing country perspective, the conventional wisdom is that unlike the case with the developed countries, an increased integration with the world economy will be beneficial to less skilled workers. However, this does not seem to be supported by the available empirical evidence, which suggests that many developing countries experienced rising wage inequality after opening to international trade. It appears possible that there is a pervasive skill bias in globalization. It is also uncertain what prospects international trade offers in creating jobs in developing countries, particularly those located in Africa and Latin America.

\section{Human rights beyond labour rights}

Since the end of the Cold War, two main visions have guided the evolution of the international law and institution: the visions of human rights and humanity and that of economic globalization. Both visions have offered challenges to traditions and understandings of sovereignty: they have given a new significance to non-state actors in the evolution and implementation of international law. Both have often given rise to demands and aspirations to global politics and constitutionalism as well as a new relationship between local, national, regional and global levels of governance. However, the legal, institutional and policy cultures of international human rights law and of international trade, financial and investment law have developed largely in isolation from one another (Howse and Teitel, 2007).

As a matter of international law, the International Covenant on Civil and Political Rights (ICCPR) and the International Covenant on Economic, Social and Cultural Rights (ICESCR) and the WTO are, in the first instance, treaty regimes. A fundamental structural characteristic of the international legal system is that of decentralization without hierarchy. Treaty norms in the ICCPR and ICESCR, and other human rights instruments have an equal legal status to those in the WTO (a few of such norms, related to prohibitions on torture and slavery have a higher status as ius cogens or preemptory norms of International law, trumping treaty obligations to the extent of inconsistency). 
A large majority of states are signatories to both the WTO Single Undertaking (the core WTI treaties), and the ICCPR and ICESCR. The principle of decentralization without hierarchy, along with that of giving a full effect to international obligations, implies the need to interpret and to develop these regimes in a complementary and consistent fashion to the possible extent. As the Report of the international Law Commission (ILC) on fragmentation of international law notes, 'In international law, there is a strong presumption against normative conflicts (Koskenniemi, 2006).

The Declaration on Trade-related Intellectual Property Rights (TRIP) and Public Health and the Kimberly (Conflict Diamonds) waiver reflect an unacknowledged debt to human rights consciousness in the WTO. The current Director-General of the WTO, Pascal Lamy, has written about globalization with a human face, and his conception of the economic sphere, including the international economic sphere, is deeply rooted in the notion of humanity. More recently, a joint study by the ILO and the WTO Secretariat which explicitly refers to the freedom of association and the right to collective bargaining as 'universally recognized Human Rights', urges their respects as such and not just for instrumental reasons of social peace, and refutes, with empirical evidence, the notion that respect for such rights harms competitiveness (Knoll, 2003).

Sen vigorously challenges the view that human rights are 'luxury goods' that poor countries cannot afford until they have achieved a certain level of prosperity; instead, the improvement of the economic welfare depends upon respect for rights in many and complex ways. More recently, Alan Sykes has noted that, generally speaking, there is a positive correlation between a country's openness to trade and its tendency to respect human rights. This puts into question the idea that poor countries should or must sacrifice human rights or postpone their realization for the sake of openness to trade, and an outwardoriented development strategy (Sykes, 2003).

\section{Liberalization of trade and health policy perspective}

Health care policy, in common, is one of the important rights. Healthcare, as one of the freedoms, is protected by human rights. In national as well as international legal systems, the expression of health policy is under high protection. (Palkova and Kudeikina 2020)

International trade also hurts the right to health directly or indirectly. In this case, it should be mentioned that the Regional Committee for the Eastern Mediterranean of World health Organization discussed, in its Forty-fifth Session, the impact of the GATT Agreements on health, and passed a resolution urging Member States to: A. Ensure that ministries of health are represented on national committees entrusted with the task of studying the negative impact of World Trade Organization agreements on the health sector; B. Conduct studies to coordinate response to World Trade Organization health-related agreements in cooperation with the Regional Office. World health Organization expressed its concerns in a statement at the Third WTO Ministerial Conference as follows - trade and public health should not be discussed in isolation from each other. Decisions made outside the health sector have tremendous influence on health outcomes, especially in poor societies. World health Organization supports the main purpose of promoting trade, that is, to improve living conditions and to raise real income. It strongly reaffirms that health is central to this development goal. The benefits to be derived from expanding trade should further the goal of improving the health of the population, especially that of poor or marginalized groups who may find themselves excluded from the process of economic growth. (WHO, 2013).

TRIPS is the importance of interpreting WTO treaties from a health policy perspective. Health policy experts and organizations were able to promote the protection of the safeguards in TRIPS for parallel importing and compulsory 
licensing by stressing that the treaty text accorded WTO members these rights. In addition, health policy activism helped stimulate subsequent state practices in the form of the Doha Declaration on the TRIPS Agreement and Public Health which reinforced WTO members' rights to use TRIPS flexibilities and safeguards for public health purposes. Treaty interpretation from a health policy perspective remains important in other areas of TRIPS as well.

The question arises whether the provisions of GATS may also provide insufficient flexibility for health policy makers, transferring the issue from the realm of treaty interpretation into treaty implementation or revision. Health concerns often seem to have insufficient weight in decisions many governments make in international forums, such as the WTO. GATS forces WTO members to think about health in connection with the growing role of services in modern economies and the impact of globalization trends, particularly on the poor. In addition, GATS establishes a process designed to progressively liberalize trade in services, and health policy-makers must be prepared to participate in this process to ensure that such liberalization unfolds in a way sensitive to the needs of national governments in ensuring the provision and regulation of health-related services. GATS "institutional framework" and particularly the dispute settlement mechanism, are also important parts of the GATS for health policy (Mattoo, Stern and Zanini, 2008).

Any liberalization under GATS should aim to produce better quality, affordable and effective health-related services, leading to a greater equity in health outcomes. Liberalization should also ensure the necessary policy and regulatory space governments required to promote and protect the health of their populations, particularly those in greatest needs. GATS creates health opportunities and challenges, especially for developing countries. GATS accords countries a considerable choice, discretion, and flexibility so that the proper management of the process of liberalization of trade in health-related services can adequately protect health. In key areas of GATS, governments face choices about the breadth and depth of liberalization of trade in health-related services and the impact of such liberalization on health policy. In fact, countries are free to decide whether liberalization in the health sector should be pursued or not and to what extent. Countries are not obliged to liberalize health services if they do not wish to do so. These choices make it imperative that health officials understand the structure and substance of GATS, collaborate with other government agencies on GATS implementation and liberalization, and act to ensure that the GATS process does not adversely affect the national health policy. (Drager Smith, 2006).

As regards to the key provisions of GATS, it creates the multilateral legal framework for international trade in nearly every type of service. The Agreement's 29 articles establish the scope of its rules' coverage, impose general obligations, structure the making of specific commitments, construct a process for progressive liberalization of trade in services and link the treaty to the WTO's dispute settlement mechanism. Although experts acknowledge that GATS has not, to date, significantly affected trade in health-related services, the potential for GATS to do so, through the progressive liberalization process, is tremendous. In the GATS 2000 negotiations, countries may be receiving requests from and may consider submitting offers to other WTO members for market access and national treatment commitments in many different health-related service sectors.

On the basis of what is mentioned above, a very interesting subject is WHO's work on GATS and policy. WHO's work on GATS has, to date, focused on collecting evidence on the potential and actual impact of GATS on the functioning of health systems. These efforts involve:

1. Collecting data on trade in healthrelated services;

2. Undertaking a wide range of countrybased studies;

3. Conducting regional and national training programs; 
4. Supporting a legal review of GATS from the perspective of health policy;

5. Developing a Handbook on Trade in Health-Related Services and GATS; and 6. Tracking and disseminating information on the GATS 2000 negotiations (Adlung and Carzaniga, 2001).

Although the environment per se is not a WTO issue, several WTO Agreements and rules are relevant to environmental issues. There have been several environmental related WTO disputes often centering on the issue of "like product". In making a determination of "likeness", WTO rules permit health risks to be taken into account. In a recent case on asbestos, the Appellate Body found the objective pursued, i.e. the preservation of human life and health, to be "both vital and important in the highest degree", and concluded that an import ban on asbestos was a "necessary" measure to protect human health (WTO, 2002).

\section{Summary}

Summarizing the results of the dissertation research, the following conclusions are presented. The International rules on trade, are necessary for four related reasons, Firstly, to restrain countries from taking trade-restrictive measures, for their own interest in the world economy. Secondly, to give traders and investors a degree of security and predictability regarding the trade policies of other countries. Thirdly, to allow for the effective protection and promotion of important societal values and interests (such as public health, a sustainable environment, consumer safety, cultural identity and minimum labour standards), while at the same time ensuring that countries mean only those measures that are necessary for the protection of these values and interests. And fourthly, to achieve a greater measure of equality economic relations. It should be noted that for the potential of international trade to be realized, there must be good governance at the national level, as well as further reduction of trade barriers and more development aids.
Without the national or international action required in these four areas, international trade will not bring prosperity to all, but, on the contrary, it is likely to result in more income inequality, social injustice, environmental degradation and cultural homogenization.

\section{References}

- Adlung $\mathrm{R}$ \& Carzaniga A. Health Services under the General Agreement on Trade in Services. Bulletin of the World Health Organization, 2001, 79(4): p. 352-364. [Online], [Retrieved January, 2020], https://www.who.int/bulletin/archive s/79(4)352.pdf

- Alben E., (2001), GATT and the Fair Wage: A Historical Perspective. 101 (6) Columbia Law Review 1410-47. [Online], [Retrieved January, 2020], https://www.jstor.org/stable/112374 8?seq=1\#metadata_info_tab_contents.

- Blouin G., Drager N., Smith R. (2006). International Trade in Health Services and the GATS: current issues and debates. The World Bank, 2006

- Charnovitz, S. (1987) 'The influence of International Labour Standards on the World Trading System: An Historical Overview' International Labour Review p. 565 .

- Ignatieff, M. (2001). Human Rights as Politics and Idolatry. NJ: Princeton University Press, 2001, 208 p.

- Grasis, J.. Compliance of the Latvian Personal Income Tax System to Preamble of the Satversme (Constitution) of the Republic of Latvia and International Obligations of the Republic of Latvia. Collection of Research Papers in Conjunction with the 6th International Scientific Conference of the Faculty of Law of the University of Latvia "Constitutional Values in Contemporary Legal Space"I 16-17 November, 2016 p.263.-271. Web of science data base.

- Howse R., Teitel, R. (2007). Beiond the Divide: The Covenant on Economic, Social and Cultural Rights and The Worlds Trade Organization. , 
Occasional Paper No. 30, Friedrich Ebert Stiftung, Geneva, Switzerland.

- Koskenniemi, M. (2006). International Law Commission, 'Fragmentation of international Law: Difficulties Arising from the Diversification and Expansion of International Law', Report of the Study group of the International Law Commission, finalized by, para.37. [Online], [Retrieved January, 2020] https://legal.un.org/ilc/documentatio n/english/a_cn4_1682.pdf

- Knoll, M. (2003) International Trade Law. Second series. London, United Kingdom.

- Langille, B. (1997). Eight Ways to Think About International Labour Standards. Journal of World Trade, Vol. 31, pp. 27-53, [Online], [Retrieved January, 2020] https://papers.ssrn.com/sol3/papers.c fm?abstract_id=1141987.

- Molatlhegi, McCrudden, Cleveland (2002). Human Rights and International Trade: A theory of Compatibility' Journal of International Economic Law 133-89. [Online], [Retrieved January, 2020], https://www.researchgate.net/publica tion/5213635_Human_Rights_Sanction s_and_International_Trade_A_Theory_o f_Compatibility.

- Mattoo, A., Robert M. Stern, Zanini G., (2008), A Handbook of International Trade in Services. p.449. Oxford.

- Palkova K, Kudeikina I. (2020) The Problems in will Expression in Civil Law Transactions and Healthcare in Case of Capacity of Individuals. European Journal of Sustainable
Development, [Online], [Retrieved January, 2020] https://ecsdev.org/ojs/index.php/ejsd /article/view/975

- Sen, A. (1999). Development as Freedom. New York: Oxford University Press.

- $\quad$ Sykes, A.O. (2003) "International Trade and Human rights: An Economic Perspective', University of Chicago Law and Economicsm Olin Working paper No.188 [Online], [Retrieved January, 2020]

https://papers.ssrn.com/sol3/papers.c fm?abstract_id=415802

- $\quad$ Trebilock,M, Howse., R., Eliason., A. (2013). The Regulation of International Trade, Routledge. New York.

- $\quad$ Trebilock,M, Howse., R., Eliason., A. (2013). The Regulation of International Trade, Routledge. New York.

- WHO (1999), Trade and public health. Statement of the World health Organization (WHO) at the Third WTO Ministerial Conference, 30 November to 3 December. [Online], [Retrieved January, 2020] Seattle, https://www.wto.org/english/thewto_ e/minist_e/min99_e/english/about_e/ presspack_english.pdf

- WTO (2002), Agreements and Public Health. [Online], [Retrieved January, 2020]

https://www.wto.org/english/res_e/b ooksp_e/who_wto_e.pdf 